\title{
Oral metronidazole as antibiotic prophylaxis for patients with nonperforated appendicitis
}

This article was published in the following Dove Press journal:

Clinical and Experimental Gastroenterology

6 December 201I

Number of times this article has been viewed

\section{Hassan Ravari'}

Ali Jangjoo ${ }^{2}$

Jalal Motamedifar ${ }^{2}$

Kasra Moazzami ${ }^{3}$

'Vascular and Endovascular Surgery Research Center, Imam Reza Hospital, Faculty of Medicine, Mashhad University of Medical Sciences, Mashhad, ${ }^{2}$ Department of General Surgery, Mashhad University of Medical Sciences, Imam Reza Hospital, Mashhad, ${ }^{3}$ Department of General Surgery, Tehran University of Medical Sciences, Sina Hospital, Tehran, Iran
Correspondence: Hassan Ravari Vascular and Endovascular Surgery Research Center, Imam Reza Hospital, Faculty of Medicine, Mashhad University of Medical Sciences, Mashhad, Iran 9137913312

Tel/fax +98 51 I 852531 I

Email hassanravari@yahoo.com
Background: The rate of wound infection after appendectomy without antibiotic prophylaxis is $10 \%-30 \%$. The role of prophylactic antibiotic therapy in nonperforated appendicitis is still controversial. Metronidazole is against anaerobic organisms and its bioavailability after oral and parenteral administration has been shown to be similar. The objective of the present study is to compare the infective complications rate after open appendectomy for nonperforated appendicitis receiving either oral or intravenous metronidazole as prophylaxis.

Methods and Materials: From June 2007 to July 2009 in a randomized controlled trial, 204 patients with nonperforated appendicitis underwent an open appendectomy; 122 male and 82 female with mean age of 25 years. Among these, 102 (case group) received oral metronidazole and in 102 (control group) metronidazole was administered intravenously before surgery. The rate of wound infection and duration of the postoperative hospital stay was studied in the two groups.

Results: The rate of wound infection was not significantly different in the two groups. ( $6 \%$ and $4 \%$ in study and control group, respectively, $P=0.861)$. Also the hospital stay was equal in two groups (2.3 days and 2.7 days in study and control group, respectively, $P=0.293$ ).

Conclusion: Single dose of oral metronidazole prior to operation can provide a sufficient prophylaxis for nonperforated appendicitis; so, it can be substitute the parental route of antibiotic administration.

Keywords: antibiotic prophylaxis, wound infection, appendectomy, complications

\section{Introduction}

Acute appendicitis is the most common cause of acute abdominal pain requiring surgical intervention, and it is the most frequently performed emergency operation. ${ }^{1}$ The efficacy of antibiotic prophylaxis in patients undergoing appendectomy has been examined in several studies. ${ }^{2-11}$ Without any pre- or perioperative antibiotic prophylaxis, wound infection rates in patients undergoing appendectomy are $10 \%$ or more when the appendix is normal, increasing to $30 \%$ when the appendix is phlegmonous or gangrenous. ${ }^{12}$

In patients with perforated appendicitis, preoperative administration of antibiotics has proven to be effective in reducing wound complications that result from the heavy intraperitoneal and wound microbial contamination associated with this condition. ${ }^{13}$ However, the role of such prophylactic therapy in nonperforated appendicitis is still controversial. ${ }^{14,15}$

There are a number of antibiotics that can be used as long as they provide activity against enteric anaerobic and Gram-negative bacteria such as cefoxitin or cefotetan and metronidazole. ${ }^{16}$ Metronidazole is among the most effective drugs against anaerobic 
organisms and has been widely used either parenterally or intrarectally in appendicitis. ${ }^{17-20}$ The bioavailability of metronidazole after oral and parenteral administration has been shown to be similar, ${ }^{21,22}$ however, the former is much more cost-effective and easier to supply. In elective colon surgeries, the oral route of the drug has been shown to be effective in reducing wound infections. ${ }^{23,24}$ As in acute surgical conditions such as appendicitis, where there is a possibility of decreased serum levels secondary to inadequate absorption, it is not known whether oral administration could be as effective as other routes of administration.

As the role of oral antibiotics in the treatment of acute appendicitis following appendectomy has not been adequately addressed in the literature, the objective of the present study is to compare the infective complication rate after open appendectomy for nonperforated appendicitis receiving either oral or intravenous metronidazole as prophylaxis.

\section{Methods}

This prospective randomized study was conducted in Emam Reza and Ghaem Hospitals (Mashhad University of Medical Sciences) between June 2007 and July 2009 in 204 pediatric and adult patients. After the study was approved by the Institutional Ethics Committee, patients were divided into study and control groups.

Patients with were excluded from the study if they: had diabetes mellitus, were on steroid therapy, had a known drug allergy to the study antibiotics, were aged $<5$ or $>60$ years, were pregnant, and/or had received antibiotics within 72 hours before referral. In addition, those patients who, at operation, were found to have a ruptured appendix or bacterial peritonitis not originating from the appendix were excluded from the study.

After informed consent was taken, the study group received oral metronidazole $(500 \mathrm{mg} / \mathrm{dose}$ for adults, $7-10 \mathrm{mg} / \mathrm{kg} /$ dose for those aged $<15$ years) $2-3$ hours before operation. In the control group, metronidazole $(500 \mathrm{mg} / \mathrm{dose}$ for adults, $7-10 \mathrm{mg} / \mathrm{kg} /$ dose for those aged $<15$ years) was administered intravenously for 20-30 minutes during the hour before surgery.

Demographic data, including sex, age, weight, height, arterial blood pressure, clinical diagnosis, operative procedure (duration and type of operation), and medical history, were collected for all patients.

Uncomplicated appendicitis was defined as acutely inflamed appendicitis without perforation (clean-contaminated wound). To maintain uniformity in the operative procedure, a standard operative protocol was followed. Open appendectomy was performed through right lower-quadrant incision by muscle-splitting approach and the appendices were removed in the standard fashion. Peritoneum was mopped dry with no peritoneal washing after the appendices were removed. The peritoneum, oblique muscles, and the Scarpa's fascia were closed with $3 / 0$ vicryl sutures and the skin was closed with interrupted vertical mattress with $3 / 0$ nylon in a standard manner. No local antibiotics were given.

Wounds were inspected daily for signs of infection, defined as discharge of pus requiring surgical drainage or sign of cellulites requiring antibiotic therapy. They were reevaluated 1 and 2 weeks after operation in the clinic and were asked to be referred again if any further problems arose.

Medication charges calculated for this study were estimated based on the current price within the authors' institution. These were compiled using the current base price of each dose of medication in addition to the nurse dispensing fee for each dose. Assessment was also made of the duration of postoperative hospital stay and the hospital cost incurred for each patient.

Outcomes of surgery were compared using one-way analysis of variance test. Fisher's exact and chi-square tests were used to compare categorical data. Contingency tables were constructed to analyze the relations between surgical wound infections and the other study variables: use and duration of antibiotic prophylaxis, sex, age, length of preoperative stay, type of operation, and duration of operation.

\section{Results}

During the study period, 348 patients with clinical diagnoses of acute appendicitis undergoing open appendectomy were considered for the study. Ninety-six patients were excluded preoperatively because of previously listed exclusion criteria. Demographic and perioperative data are shown in Table 1. Also, in 48 cases, the appendix was found to be perforated or an appendiceal abscess was discovered intraoperatively and these patients were excluded as well.

Finally, 204 patients met the criteria of the study and were subjected to final analysis. Among these, 122 were male and 82 female. Patients ranged in age from 7 to 57 years, with

Table I Demographic and perioperative data

\begin{tabular}{|c|c|c|c|}
\hline & Study group & Control group & $P$-value \\
\hline Mean age (years) & $25.4 \pm 13.6$ & $24.8 \pm 9.88$ & 0.099 \\
\hline Male/female & $57 / 45$ & $65 / 37$ & 0.414 \\
\hline $\begin{array}{l}\text { Duration of symptoms } \\
\text { (hours) }\end{array}$ & $19.7 \pm 12.3$ & $17.4 \pm 11.6$ & 0.348 \\
\hline $\begin{array}{l}\text { Duration of operation } \\
\text { (minutes) }\end{array}$ & $48 \pm 38$ & $53 \pm 23$ & 0.107 \\
\hline
\end{tabular}


Table 2 Distribution by age

\begin{tabular}{lll}
\hline Age $(\mathbf{y})$ & Study group $(\mathbf{n})$ & Control group $(\mathbf{n})$ \\
\hline $0-10$ & 4 & 3 \\
$1 \mid-20$ & 38 & 49 \\
$21-30$ & 23 & 24 \\
$31-40$ & 20 & 12 \\
$4 I-50$ & 12 & 10 \\
$5 I-60$ & 5 & 4 \\
\hline
\end{tabular}

a mean of 25 years. Distribution by age in two groups are shown in Table 2. There was no significant difference between the groups in terms of age or sex distribution (Table 1). Also, no significant differences could be found between the two groups of patients with regard to duration of symptoms before admission and the duration of surgery (Table 1).

Among the 204 patients enrolled in the study, ten (5\%) had wounds which became infected, six $(6 \%)$ in the study group and four (4\%) in the control group. The rate of infection did not show any significant difference between the groups $(P=0.861)$. Also, duration of hospital stay was equal in uncomplicated appendicitis in the study group and the control groups $(P=0.293)$ (Table 3$)$.

\section{Discussion}

In patients with nonperforated appendicitis, the use of prophylactic antibiotics has been questioned in some studies, ${ }^{25-27}$ however, a large number of reports ${ }^{28-32}$ indicate that, without prophylaxis, the infection rate is significant, and ranges from $10 \%$ to $20 \%$. In the present study, the infection rate after the use of antibiotic prophylaxis was around 5\%, which is in agreement with other studies. ${ }^{4,33-38}$

For prophylaxis, different antibiotic regimens have been suggested. The American Society of Health System Pharmacists recommends prophylaxis with cephalosporins for uncomplicated appendicitis, ${ }^{39,40}$ with metronidazole and gentamicin only considered an alternative in cases of penicillin allergy. However, the latter drugs may have an economic advantage. In the present study, metronidazole was administered either parentally or orally and was shown to be effective in reducing the rate of wound infection. Also, the oral administration was associated with significant cost savings.

Oral metronidazole has been demonstrated to have a bioavailability of nearly $100 \%$, which is almost identical

Table 3 Rate of infection and duration of hospital stay

\begin{tabular}{llll}
\hline & Study group & Control group & $\boldsymbol{P}$-value \\
\hline Rate of infection (n) \% & $(6) 6 \%$ & $(4) 4 \%$ & 0.861 \\
Hospital stay (days) & $2.3 \pm 0.8$ & $2.7 \pm 1.1$ & 0.293 \\
\hline
\end{tabular}

to intravenous administration. ${ }^{21,22}$ It also approaches its maximum concentration about 1 hour after ingestion. ${ }^{21}$ In the present study, the rates of wound infection were similar between the cases in the studied group (oral route) to those observed in the control group (intravenous route). This finding suggests that metronidazole can be administered preoperatively orally in most patients suffering from nonperforated appendicitis to decrease the postoperative complication rate.

In the present study, a single dose of antibiotic prophylaxis was administered before the incision. It has been shown in recent studies that a single dose of prophylactic antibiotic is adequate to prevent infective complications following open appendectomy for nonperforated appendicitis. . $^{37,38,41,42}$ Even in complicated appendicitis, prolonged use of antibiotics were not shown to decrease the rate of postoperative infective complications. ${ }^{41,42}$

In conclusion, this study has shown that a single dose of oral metronidazole prior to operation can provide sufficient prophylaxis for nonperforated appendicitis, indicating that oral administration of antibiotics can be substituted for parenteral administration.

\section{Disclosure}

The authors report no conflicts of interest in this work.

\section{References}

1. Andersen BR, Kallehave FL, Andersen HK. Antibiotics versus placebo for prevention of postoperative infection after appendicectomy. Cochrane Database Syst Rev. 2005;2:CD001439.

2. Fraser JD, Aguayo P, Leys CM, et al. A complete course of intravenous antibiotics vs a combination of intravenous and oral antibiotics for perforated appendicitis in children: a prospective, randomized trial. J Pediatr Surg. 2010;45(6):1198-1202.

3. St Peter SD, Tsao K, Spilde TL, et al. Single daily dosing ceftriaxone and metronidazole vs standard triple antibiotic regimen for perforated appendicitis in children: a prospective randomized trial. J Pediatr Surg. 2008;43(6):981-985.

4. Zerem E, Salkic N, Imamovic G, Terzić I. Comparison of therapeutic effectiveness of percutaneous drainage with antibiotics versus antibiotics alone in the treatment of periappendiceal abscess: is appendectomy always necessary after perforation of appendix? Surg Endosc. 2007; 21(3):461-466.

5. Koch A, Zippel R, Marusch F, Schmidt U, Gastinger I, Lippert H Prospective multicenter study of antibiotic prophylaxis in operative treatment of appendicitis. Dig Surg. 2000;17(4):370-378.

6. Liberman MA, Greason KL, Frame S, Ragland JJ. Single-dose cefotetan or cefoxitin versus multiple-dose cefoxitin as prophylaxis in patients undergoing appendectomy for acute nonperforated appendicitis. $J \mathrm{Am}$ Coll Surg. 1995;180(1):77-80.

7. Gorecki P, Schein M, Rucinski JC, Wise L. Antibiotic administration in patients undergoing common surgical procedures in a community teaching hospital: the chaos continues. World J Surg. 1999;23(5): 429-432.

8. Tönz M, Schmid P, Kaiser G. Antibiotic prophylaxis for appendectomy in children: critical appraisal. World J Surg. 2000;24(8):995-998. 
9. Charalambous C, Tryfonidis M, Swindell R, Lipsett AP. When should old therapies be abandoned? A modern look at old studies on topical ampicillin. J Infect. 2003;47(3):203-209.

10. Lau WY, Fan ST, Chu KW, et al. Cefoxitin versus gentamicin and metronidazole in prevention of post-appendicectomy sepsis: a randomized, prospective trial. J Antimicrob Chemother. 1986;18(5):613-619.

11. al-Dhohayan A, al-Sebayl M, Shibl A, al-Eshalwy S, Kattan K, al-Saleh M. Comparative study of augmentin versus metronidazole/ gentamicin in the prevention of infections after appendicectomy. Eur Surg Res. 1993;25(1):60-64.

12. Bauer T, Vennits B, Holm B, et al. Antibiotic prophylaxis in acute nonperforated appendicitis. The Danish Multicenter Study Group III. Ann Surg. 1989;209(3):307-311.

13. Hale DA, Molloy M, Pearl RH, Schutt DC, Jaques DP. Appendectomy: a contemporary appraisal. Ann Surg. 1997;225(3):252-261.

14. Campbell WB. Prophylaxis of infection after appendicectomy: a survey of current surgical practice. Br Med J. 1980;281(6255):1597-1600.

15. Kizilcan F, Tanyel FC, Büyükpamukçu N, Hiçsönmez A. The necessity of prophylactic antibiotics in uncomplicated appendicitis during childhood. J Pediatr Surg. 1992;27(5):586-588.

16. Lally KP, Cox CS, Andrassy RJ. Appendix. In: Townsend CM, Beauchamp RD, Evers BM, Mattox KL, editors. Sabiston Textbook of Surgery. 17th ed. Philadelphia, PA: Elsevier Saunders; 2010:1381-1400.

17. Gottrup F. Prophylactic metronidazole in prevention of infection after appendicectomy: report of a double blind trial. Acta Chir Scand. 1979;146:133-136.

18. Rodgers J, Ross D, McNaught W, Gillespie G. Intrarectal metronidazole in the prevention of anaerobic infections after emergency appendicectomy: a controlled clinical trial. Br J Surg. 1979;66(6):425-427.

19. Willis AT, Ferguson IR, Jones PH, et al. Metronidazole in prevention and treatment of bacteroides infections after appendicectomy. $\mathrm{Br}$ Med J. 1976;1(6005):318-321.

20. Flannigan GM, Clifford RP, Carver RA, Yule AG, Madden NP. Antibiotic prophylaxis in acute appendicitis. Surg Gynecol Obstet. 1983;156(2):209-211.

21. Ralph ED. Clinical pharmacokinetics of metronidazole. Clin Pharmacokinet. 1983;8(1):43-62.

22. Houghton GW, Thorne PS, Smith J, Templeton R, Collier J. Comparison of the pharmacokinetics of metronidazole in healthy female volunteers following either a single oral or intravenous dose. Br J Clin Pharmacol. 1979;8(4):337-341.

23. Willis AT, Ferguson IR, Jones PH, et al. Metronidazole in prevention and treatment of bacteroides infections in elective colonic surgery. Br Med J. 1977;1(6061):607-610.

24. Goldring J, McNaught W, Scott A, Gillespie G. Prophylactic oral antimicrobial agents in elective colonic surgery. A controlled trial. Lancet. 1975;2(7943):997-1000.

25. McGreal GT, Joy A, Manning B, et al. Antiseptic wick: does it reduce the incidence of wound infection following appendectomy? World $J$ Surg. 2002;26(5):631-634.

26. Górecki WJ, Grochowski JA. Are antibiotics necessary in nonperforated appendicitis in children? A double blind randomized controlled trial. Med Sci Monit. 2001;7(2):289-292.
27. Pinto DJ, Sanderson PJ. Rational use of antibiotic therapy after appendicectomy. Br Med J. 1980;280(6210):275-277.

28. Fine M, Busuttil RW. Acute appendicitis: efficacy of prophylactic preoperative antibiotics in the reduction of septic morbidity. Am J Surg. 1978;135(2):210-212.

29. Leigh DA, Pease R, Henderson H, Simmons K, Russ R. Prophylactic lincomycin in the prevention of wound infection following appendicectomy: a double blind study. Br J Surg. 1976;63(12):973-977.

30. Donovan IA, Ellis D, Gatehouse D, et al. One-dose antibiotic prophylaxis against wound infection after appendicectomy: a randomized trial of clindamycin, cefazolin sodium and a placebo. Br J Surg. 1979;66(3):193-196.

31. Foster PD, O'Toole RD. Primary appendectomy. The effect of prophylactic cephaloridine on postoperative wound infection. JAMA. 1978 3;239(14):1411-1412.

32. Tanphiphat $\mathrm{C}$, Sangsubhan C, Vongvaravipatr $\mathrm{V}$, et al. Wound infection in emergency appendicectomy: a prospective trial with tropical ampicillin and antiseptic solution irrigation. Br J Surg. 1978;65(2):89-91.

33. Busuttil RW, Davidson RK, Fine M, Tompkins RK. Effect of prophylactic antibiotics in acute nonperforated appendicitis: a prospective, randomized, double-blind clinical study. Ann Surg. 1981;194(4): 502-509.

34. Winslow RE, Dean RE, Harley JW. Acute nonperforating appendicitis. Efficacy of brief antibiotic prophylaxis. Arch Surg. 1983;118(5): $651-655$.

35. Browder W, Smith JW, Vivoda LM, Nichols RL. Nonperforative appendicitis: a continuing surgical dilemma. J Infect Dis. 1989;159(6): 1088-1094.

36. Shubing W, Litian Z. Preventing infection of the incision after appendectomy by using metronidazole preoperatively to infiltrate tissues at the incision. Am J Surg. 1997;174(4):422-424.

37. Cervantes-Sánchez CR, Gutiérrez-Vega R, Vázquez-Carpizo JA, Clark P, Athié-Gutiérrez C. Syringe pressure irrigation of subdermic tissue after appendectomy to decrease the incidence of postoperative wound infection. World J Surg. 2000;24(1):38-41; discussion 41-42.

38. Kasatpibal N, Nørgaard M, Sørensen HT, Schønheyder HC, Jamulitrat S, Chongsuvivatwong V. Risk of surgical site infection and efficacy of antibiotic prophylaxis: a cohort study of appendectomy patients in Thailand. BMC Infect Dis. 2006;6:111.

39. Fennessy BG, O’Sullivan MJ, Fulton GJ, Kirwan WO, Redmond HP. Prospective study of use of perioperative antimicrobial therapy in general surgery. Surg Infect (Larchmt). 2006;7(4):355-360.

40. Söderquist-Elinder C, Hirsch K, Bergdahl S, Rutqvist J, Frenckner B. Prophylactic antibiotics in uncomplicated appendicitis during childhooda prospective randomised study. Eur J Pediatr Surg. 1995;5(5): 282-285.

41. Tijerina J, Velasco-Rodríguez R, Vásquez C, Melnikov V, Rodriguez S. Effectiveness of a systemic antibiotic followed by topical ionized solution as surgical site infection prophylaxis. J Int Med Res. 2010;38(4): 1287-1293.

42. Sookpotarom P, Khampiwmar W, Termwattanaphakdee T. Vigorous wound irrigation followed by subcuticular skin closure in children with perforated appendicitis. J Med Assoc Thai. 2010;93(3):318-323.
Clinical and Experimental Gastroenterology

\section{Publish your work in this journal}

Clinical and Experimental Gastroenterology is an international, peerreviewed, open access journal, publishing all aspects of gastroenterology in the clinic and laboratory, including: Pathology, pathophysiology of gastrointestinal disease; Investigation and treatment of gastointestinal disease; Pharmacology of drugs used in the alimentary tract;

\section{Dovepress}

Immunology/genetics/genomics related to gastrointestinal disease. This journal is indexed on CAS. The manuscript management system is completely online and includes a very quick and fair peer-review system. Visit http://www.dovepress.com/testimonials.php to read real quotes from published authors. 